УДК 619: $343.983: 636.2 .05: 611.71$

(C) 2015

Абузнайд Карем Р. С., аспірант

(науковий керівник - доктор ветеринарних наук I. В. Яценко)

Харківська державна зооветеринарна академія

\title{
ДИНАМІКА ЛІНІЙНИХ МОРФОМЕТРИЧНИХ ПАРАМЕТРІВ ВЕНТРАЛЬНОЇ ПОВЕРХНІ НОСО-МОЗКОВОГО ВІДДІЛУ ЧЕРЕПА ВЕЛИКОЇ РОГАТОЇ ХУДОБИ ЗАЛЕЖНО ВІД ВІКУ ТА СТАТІ
}

\section{Рецензент - доктор ветеринарних наук, професор І. О. Жукова}

Лінійні морфометричні параметри вентральної поверхні носо-мозкового відділу черепа як самок, так $i$ самиів ВРX достовірно збільшуються від народження до 10-річного віку. В динамічі морфометричних параметрів вентральної поверхні носо-мозкового відділу черепа реєструється два періоди: домежовий i постмежовий. Виявлені вікові закономірності метричних параметрів вентральної поверхні носомозкового відділу черепа ВРХ покладено в основу способу визначення віку та статі тварини за інформативними морфометричними параметрами.

Ключові слова: череп, краніометрія, велика рогата худоба, вік, стать, судово-ветеринарна експертиза.

Постановка проблеми. У практиці ветеринарної медицини визначати видову, вікову і статеву належність тварини за окремими фрагментами іiі тіла доводиться під час проведення судово-ветеринарної експертизи на запит правоохоронних органів під час розслідування правопорушень. Використання 3 цією метою зоотехнічної документації, з'ясовування ступеня стирання жувальних поверхонь зубів, підрахунок кількості кілець на роговій капсулі та інше [2] є недостатнім, або й взагалі неможливим. Це вимагає розробки, адаптації та залучення більш складних методів дослідження [3].

Аналіз останніх досліджень і публікацій, у яких започатковано розв'язання проблеми. Найбільш інформативним серед остеологічних об'єктів за характером ознак є скелет, і особливо череп. Суттєве значення черепа в цілому, і носомозкового відділу зокрема, полягає в тому, що він має ознаки, котрі входять до показників, що достовірно характеризують видову, статеву й вікову належність тварини $[1,6,4,5]$.

Мета роботи - дослідити динаміку лінійних морфометричних параметрів вентральної поверхні носо-мозкового відділу черепа великої рогатої худоби залежно від віку та статі.

Завдання:

1) виявити закономірності динаміки лінійних морфометричних параметрів вентральної поверх- ні носо-мозкового відділу черепа ВРХ залежно від віку і статі;

2) з'ясувати можливість використання цих параметрів для розробки способу діагностики віку і статі ВРХ за цими параметрами.

Матеріали і методи досліджень. Досліджували носо-мозковий відділ черепа від 88 голів самців та 88 голів самок ВРХ української червоно-рябої породи віком від новонароджених до 10 років. Загальна кількість досліджуваного кісткового матеріалу становила 176 черепів. Всю вибіркову сукупність було розбито на 11 вікових груп для самок. Вимірювання вентральної поверхні носо-мозкового відділу черепа ВРХ здійснювали за методикою описаною в нашій роботі [7]. Математико-статистичну обробку результатів вимірювань проводили із застосуванням методів варіаційної статистики із залученням критеріїв перевірки статистичних гіпотез 3 використаннями комп'ютерних програм Microsoft Excel та Maple-12.

Результати досліджень. Проаналізовано 8 абсолютних морфометричних парамерів вентральної поверхні носо-мозкового відділу черепа BPX у віковому діапазоні від народження до 10річного віку. Надалі ці параметри використані нами як базові для розробки способу визначення віку і статі ВРХ. Порівняльно-морфометричний аналіз вентральної поверхні носо-мозкового відділу черепа ВРХ статево-вікових груп досліджених тварин показав наступне.

Довжина черепа ВРХ обох статей збільшується від народження до 120-місячного віку у самців та самок (11-та вікова група), причому інтенсивність темпу збільшення цього виміру у самців і самок майже однакова (рис. 1).

Найменше значення довжини черепа реєструється у тварин обох статей 1-ї вікової групи (0-2 міс.), водночас значення цього виміру в самців становить 215,13 $\pm 3,52$ мм, що має тенденцію до збільшення на 0,25 \% проти значення аналогічного виміру самок $(215,67 \pm 0,92$ мм). 


\section{СТОРІНКА МОЛОДОГО ВЧЕНОГО}

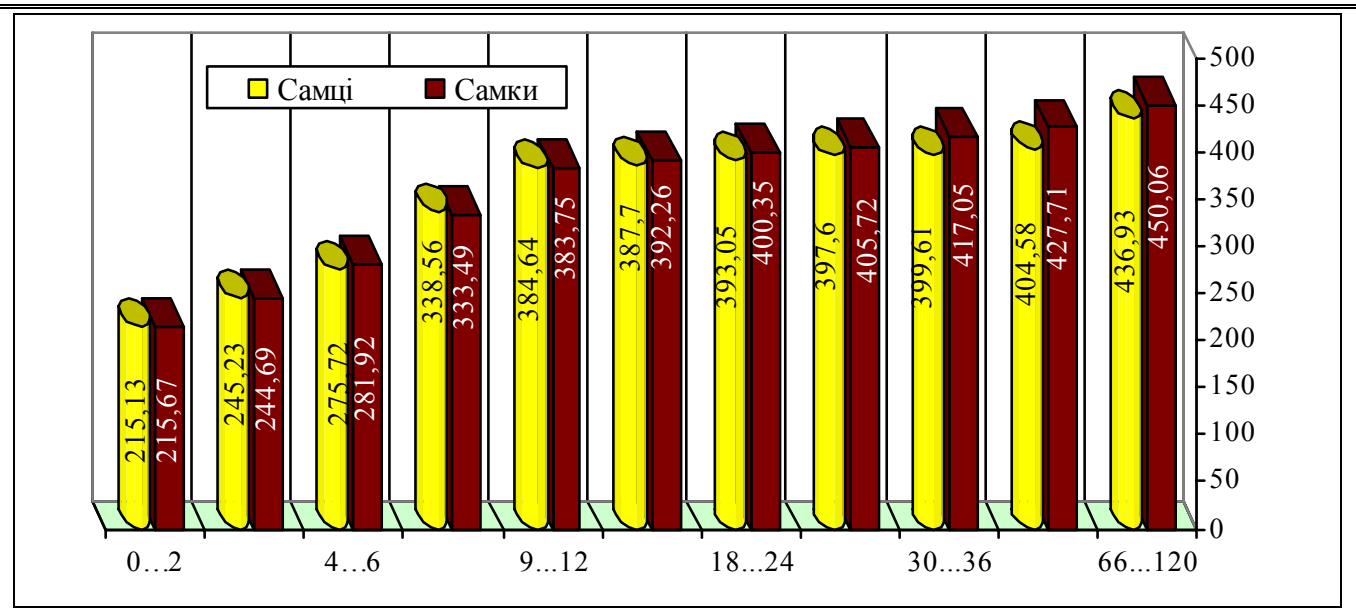

Рис. 1. Довжсина черепа ВРX

Показник аналізованого морфометричного виміру продовжує достовірно збільшуватися $(\mathrm{p} \leq 0,001)$ до 10 -місячного віку. Далі, до кінця терміну дослідження динаміка довжини черепа корів і биків $\epsilon$ стабільною і хоча має достовірну різницю у міжгрупових сукупностях $(\mathrm{p} \leq 0,05)$, проте ця різниця незначна.

Максимального значення довжина черепа досягає у самців і самок 11-ї вікової групи (60-120 міс.). Остеометричним аналізом встановлено, що в цей період постнатального онтогенезу абсолютне значення аналізованого параметра черепів самців ВРX 11-ї вікової групи становить $436,93 \pm 1,15$ мм, що на $2,92 \%(\mathrm{p} \leq 0,05)$ менше у порівнянні 3 аналогічним показником самок $(450,06 \pm 10,39$ мм).

Межове вікове значення довжини черепа становить для самців 10 міс., а для самок - 20 місяців.

Довжина беззубого краю носо-мозкового відділу черепа ВРX обох статей збільшується від народження до 120-місячного віку у самців та самок (рис. 2). Найменше значення довжини беззубого краю носо-мозкового відділу черепа реєструється у тварин обох статей 1-ї вікової групи (0-2 міс.), водночас значення цього виміру в самців становить $58,33 \pm 0,65$ мм, що має тенденцію до збільшення на 0,70 \% проти значення аналогічного виміру самок $(57,92 \pm 0,71 \mathrm{мм})$.

Довжина беззубого краю носо-мозкового відділу черепа самців ВРХ достовірно збільшується від народження до 9-місячного віку $(\mathrm{p} \leq 0,001)$. У період з 9- до 12-місячного віку значення цього остеометричного показника майже не змінюється, а вже з 12- до 18-місячного віку збільшується $(\mathrm{p} \leq 0,001)$. Період постнатального онтогенезу самців характеризується тим, що довжина беззубого краю, хоч і збільшується з віком, проте це збільшення є незначним. В період з 66- до 120 місячного віку аналізований вимір збільшується більш інтенсивно $(\mathrm{p} \leq 0,001)$.

Вікова динаміка довжини беззубого краю носо-мозкового відділу черепа самок ВРХ стрімко збільшується від народження до 12-місячного віку. Період з 12- до 30-місячного віку характеризується зменшенням темпів цього виміру $(\mathrm{p} \leq 0,05)$, а з 30- до 120 -місячного віку аналізований остеометричний параметр збільшується більш інтенсивно ( $\mathrm{p} \leq 0,01)$.

Інтенсивність темпу збільшення цього виміру у міжстатевій сукупності самців і самок від народження до 12-місячного віку майже однакова, проте 3 12- до 36-місячного віку - довжина беззубого краю у самців більша за самок $(\mathrm{p} \leq 0,05)$, a з 30-місячного віку до кінця терміну дослідження значення аналізованого виміру у самців хоч $\mathrm{i}$ має тенденцію до збільшення проти самок, однак ця різниця незначна.

Максимального значення довжина беззубого краю носо-мозкового відділу черепа ВРХ досягає у самців і самок 11-ї вікової групи (60-120 місяців). Остеометричним аналізом встановлено, що в цей період постнатального онтогенезу абсолютне значення аналізованого параметра черепів самців ВРX 11-ї вікової групи становить $128,34 \pm 1,08$ мм, що на $1,17 \%$ менше у порівнянні 3 аналогічним показником самок $(129,86 \pm 1,09$ мм).

Таким чином, встановлені особливості динаміки довжини беззубого краю носо-мозкового відділу черепа ВРХ, очевидно, можна пояснити більш інтенсивним розвитком зубних рядів у самців у порівнянні з самками.

Межове вікове значення довжини беззубого краю становить для самців 15 місяців, а для самок - 10 місяців. 


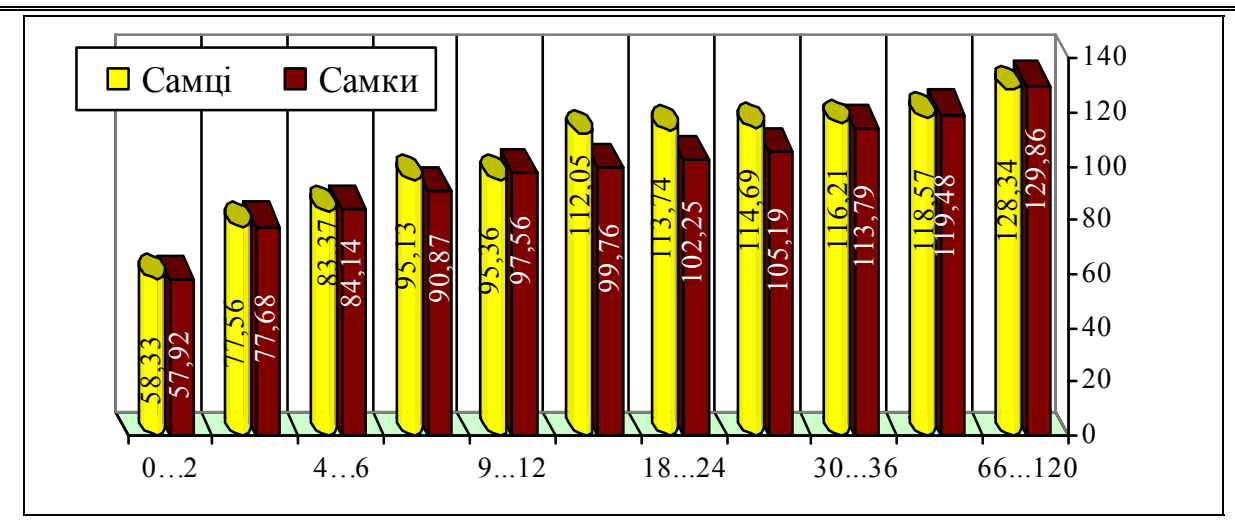

Рис. 2. Довжина беззубого краю носо-мозкового відділу черепа ВРХ

Довжина тіла потиличної кістки обох статей збільшується від народження до 120-місяців (рис. 3). Найменше значення довжини тіла потиличної кістки реєструється у тварин обох статей 1-ї вікової групи (0-2 міс.), водночас значення цього виміру в самців становить 42,08 $\pm 0,45$ мм, що на $25,50 \%$ більше $(\mathrm{p} \leq 0,001)$ проти значення аналогічного виміру самок $(33,53 \pm 0,57$ мм) (рис. 5.17). Протягом постнатального періоду онтогенезу цей краніометричний вимір самців ВРХ достовірно збільшується від народження до 4-

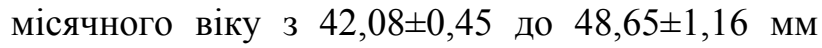
$(\mathrm{p} \leq 0,001)$. У період з 4- до 6-місячного вік значення цього остеометричного показника збільшується лише на 7 \% проти попереднього періоду, а вже з 6- до 18-місячного віку - збільшується на $16,63 \%(\mathrm{p} \leq 0,001)$. Період постнатального онтогенезу самців 3 18- до 66-місячного віку характеризується тим, що довжина тіла потиличної кістки хоч і збільшується, проте це збільшення $\epsilon$ незначним, а в міжгрупових сукупностях в цей період має лише тенденцію до збільшення. В період з 66- до 120-місячного віку аналізований вимір збільшується більш інтенсивно на $5,01 \%(\mathrm{p} \leq 0,05)$.

Вікова динаміка довжини тіла потиличної кіс- тки самок ВРХ стрімко збільшується на 38,36 \% від народження до 12-місячного віку $(\mathrm{p} \leq 0,001)$. Період $з$ 12- до 120-місячного віку характеризується зменшенням темпів цього виміру $(\mathrm{p} \leq 0,05)$, a в міжгруповій сукупності зазначений краніометричний параметр має тенденцію до збільшення.

Інтенсивність темпу збільшення цього виміру у міжстатевій сукупності самців і самок від народження до 9-місячного віку у самців більший за самок $(\mathrm{p} \leq 0,01)$, проте з 9- до кінця дослідного періоду - довжина тіла потиличної кістки у самців лише має тенденцію до збільшення проти самок, бо ця різниця незначна. Максимального значення довжина тіла потиличної кістки досягає у самців і самок 11-ї вікової групи (60-120 місяців). Остеометричним аналізом встановлено, що в 120-місячному віці абсолютне значення аналізованого параметра самців ВРX становить $66,80 \pm 0,65$ мм, що на $5,01 \%(\mathrm{p} \leq 0,05)$ більше у порівнянні 3 аналогічним показником самок $(63,61 \pm 0,88$ мм). Таким чином, встановлені особливості динаміки довжини тіла потиличної кістки ВРХ, очевидно, можна пояснити дещо більш інтенсивним розвитком зубних рядів у самців у порівнянні з самками.

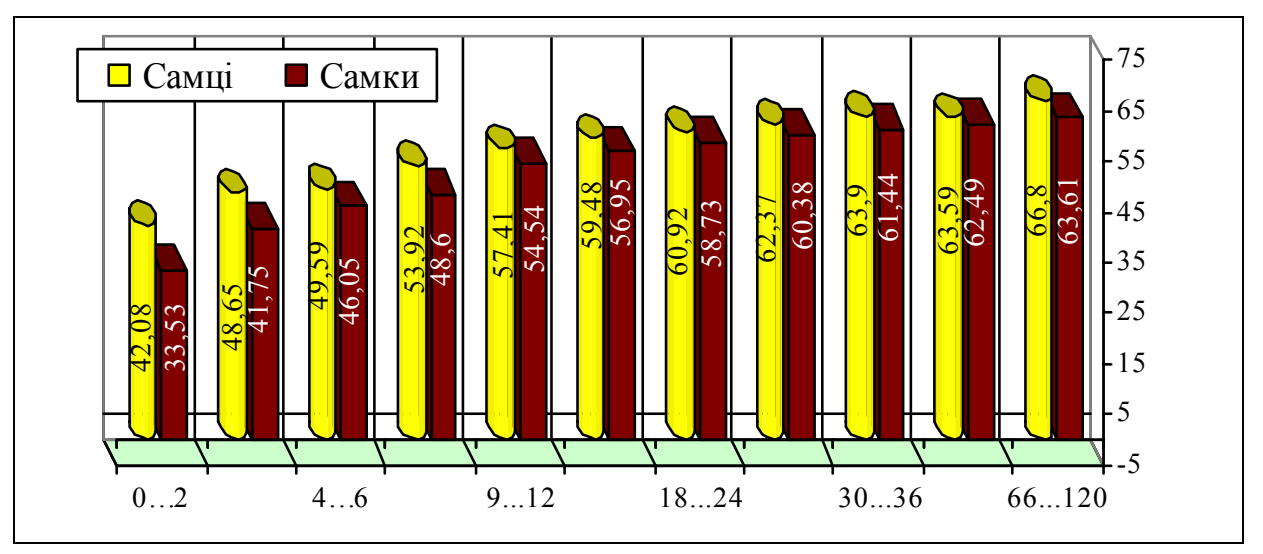

Рис. 3. Довжина тіла потиличної кіски ВРХ 


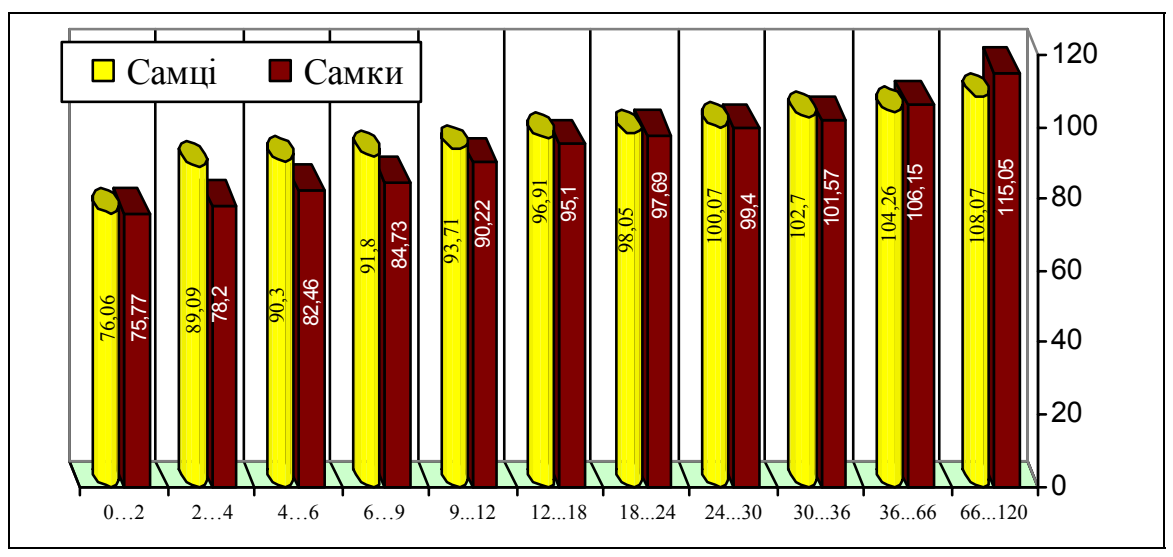

Рис. 4. Довжина хоан ВРХ

Межове вікове значення довжини тіла потиличної кістки для самців і самок становить 20 місяців.

Довжина хоан тварин обох статей збільшується від народження до 120-місячного віку у самців та самок (рис. 4). Найменше значення довжини хоан реєструється у тварин обох статей 1-ї вікової групи (0-2 міс.), водночас значення цього виміру в самців становить $76,06 \pm 1,16$ мм, що має тенденцію до збільшення на 0,38 \% проти значення аналогічного виміру самок $(75,77 \pm 1,02$ мм).

Довжина хоан самців ВРХ достовірно стрімко збільшується від народження до 4-місячного віку (3-я група) на $14,63 \%$, тобто з 76,06 11,16 до $89,09 \pm 1,17$ мм ( $\leq \leq 0,001)$. У період 3 4- (3 група) до 10-місячного віку (5 група) динаміка цього остеометричного показника сповільнюється i збільшується лише на $4,93 \%$, а вже 3 12- до 120 місячного віку значення довжини хоан продовжує достовірно збільшуватися на $13,29 \%$ (p $\leq 0,001)$ до кінця терміну дослідження.

Вікова динаміка довжини хоан самок ВРХ стрімко збільшується від народження до кінцевого терміну дослідження (120-місячного віку). Аналіз динаміки довжини хоан дав змогу виділити 3 періоди: перший - від народження самок до 18-місячного віку. За цей час розміри аналізованого краніометричного показника достовірно збільшуються на $20,33 \%(\mathrm{p} \leq 0,001)$; другий період - $з$ 18- віку до 36-місячного віку. В цей період довжина хоан самок ВРХ продовжує збільшуватися на $6,37 \%$, проте ії темпи дещо сповільнюються. Третій період - від 36- віку до 120місячного віку характеризується більш інтенсивним збільшенням зазначеного краніометричного параметру на 9,35 \% $(\mathrm{p} \leq 0,001)$.

Інтенсивність темпу збільшення довжини хоан у міжстатевій сукупності самців і самок від народження до 36-місячного віку у самців більший за самок ( $\mathrm{p} \leq 0,01)$, однак з 36-місячного віку до кінця дослідного періоду - довжина хоан у самців лише має тенденцію до зменшення проти самок, хоча ця різниця незначна.

Максимального значення довжина хоан досягає у самців і самок 11-ї вікової групи (60-120 місяців). Краніометричним аналізом встановлено, що в 120-місячному віці абсолютне значення аналізованого параметра самців ВРX становить $108,07 \pm 1,06$ мм, що на $3,55 \%(\mathrm{p} \leq 0,05)$ менше у порівнянні 3 аналогічним показником самок $(112,05 \pm 1,08$ мм). Таким чином, встановлені особливості динаміки довжини хоан ВРХ, очевидно, можна пов'язати з розвитком дихальних шляхів з віком. Межове вікове значення довжини хоан становить для самців 15 місяців, а для самок - 30 місяців. Ширина хоан самців і самок ВРХ достовірно збільшується від народження до кінця терміну дослідження, зокрема у самців - на $23,83 \%$, а у самок - на $30,47 \%$ (рис. 5). Так, найменшим це значення $\epsilon$ в 1-й віковій групі (24 міс.) і становить у самців $-32,44 \pm 0,46$ мм, що на $10,05 \%$ більше проти аналогічного краніометричного показника самок $-29,18 \pm 1,19$ мм.

Максимального значення аналізований краніометричний параметр досягає у самців і самок 11-ї вікової групи (66-120 місяців). Протягом усього періоду дослідження у міжстатевій сукупності ширина хоан у самців має тенденцію до збільшення проти аналогічного виміру черепа у самок. Ця різниця є більш суттєвою протягом усього періоду дослідження, проте з віком зменшується. Таким чином, встановлені особливості динаміки ширини хоан ВРX, як i їх довжини, очевидно, можна пов'язати з розвитком та функціонуванням дихальних шляхів тварин.

Межове вікове значення ширини хоан становить для самців 15 міс., а для самок - 20 місяців. 


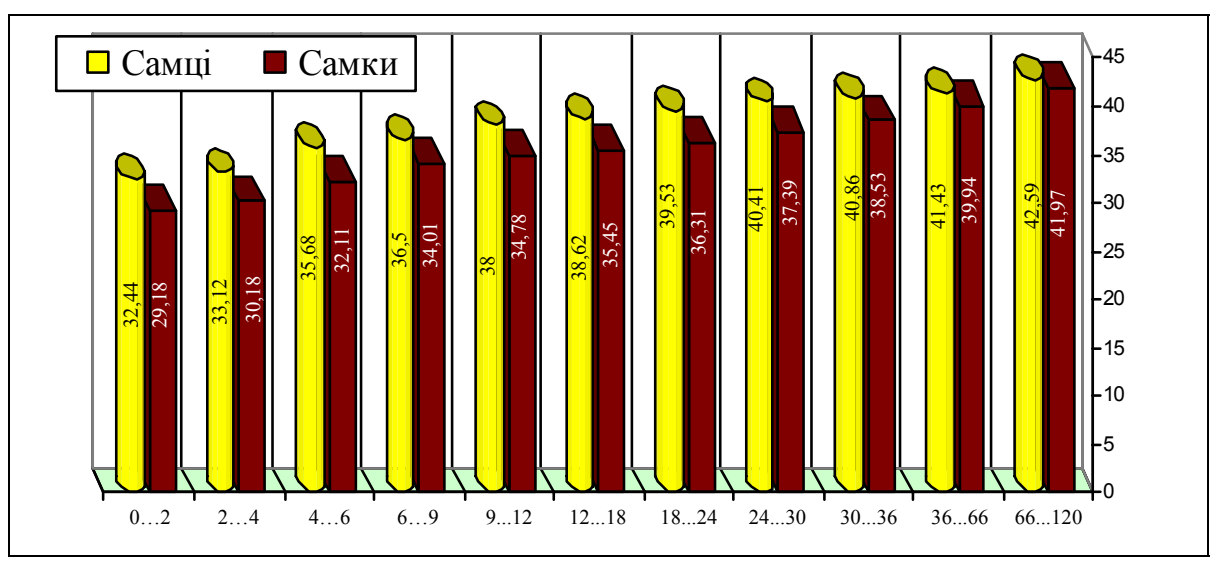

Рис. 5. Ширина хоан ВРХ

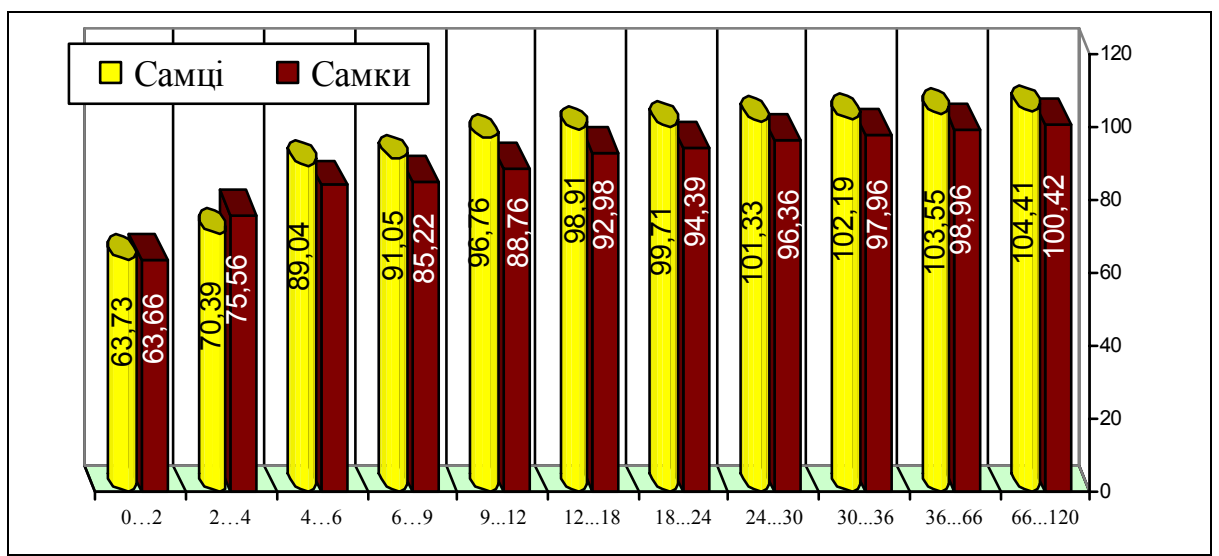

Рис. 6. Аборальна ширина кісткового піднебіння ВРX

Аборальна ширина кісткового піднебіння самців і самок ВРХ достовірно збільшується від народження до кінця терміну дослідження, зокрема у самців - на $38,96 \%$, а у самок - на $36,61 \%$ (рис. 6). Так, найменшим це значення $є$ в 1-й віковій групі (2-4 міс.) і становить у самців $63,73 \pm 0,50$ мм, що має тенденцію до збільшення на $0,11 \%$ проти аналогічного краніометричного показника самок $-63,66 \pm 0,49$ мм.

Максимального значення аналізований краніометричний параметр досягає у самців і самок 11-ї вікової групи (66-120 місяців). Протягом усього періоду дослідження у міжстатевій сукупності ширина хоан у самців має тенденцію до збільшення проти аналогічного виміру черепа у самок. Ця різниця є більш суттєвою протягом усього періоду дослідження, проте з віком дещо зменшується. Таким чином, встановлені особливості динаміки аборальної ширини кісткового піднебіння ВРХ, очевидно, можна пов'язати 3 розвитком і функціонуванням органів ротоглотки.

Межове вікове значення аборальної ширини кісткового піднебіння становить для самців 15 місяців, а для самок - 25 місяців.

Ростральна ширина кісткового піднебіння сам- ців і самок ВРХ достовірно збільшується від народження до кінця терміну дослідження, зокрема у самців - на $28,96 \%$, а у самок - на $31,40 \%$ (рис. 7). Так, найменшим це значення є в 1-й віковій групі (2-4 міс.) і становить у самців $69,99 \pm 1,74$ мм, що має тенденцію до збільшення на 5,58 \% проти аналогічного краніометричного показника самок $-66,29 \pm 3,28$ мм.

Максимального значення аналізований краніометричний параметр досягає у самців і самок 11-ї вікової групи (66-120 міс.) - 98,52 $\pm 0,70$ мм та 96,63 $\pm 1,02$ мм відповідно.

Від народження до 18-місячного віку у міжстатевій сукупності ростральна ширина кісткового піднебіння самців має тенденцію до збільшення проти аналогічного виміру черепа самок. 3 18- до 66-місячного віку ця закономірність змінюється і величина аналізованого виміру самок мають тенденцію до збільшення проти аналогічного виміру самців. В останній період дослідження (66-120-місячний вік), ростральна ширина кісткового піднебіння самців стає знову дещо більшою за значення цього виміру у самок. 


\section{СТОРІНКА МОЛОДОГО ВЧЕНОГО}

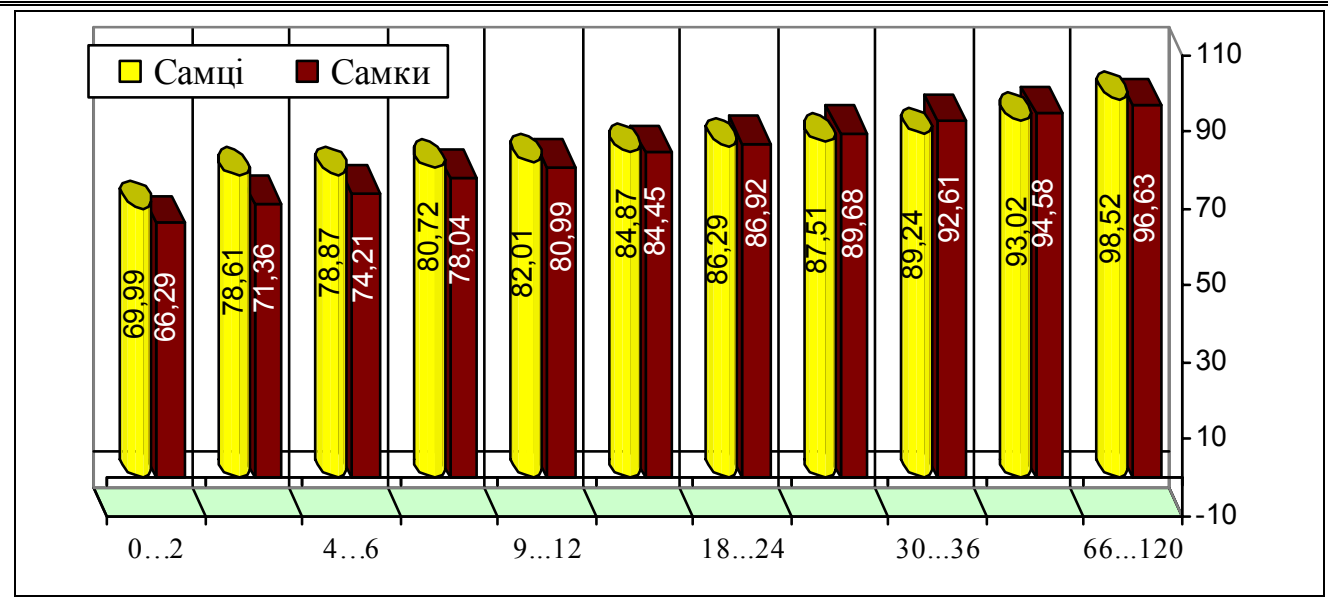

Рис. 7. Ростральна ширина кісткового піднебіння ВРХ

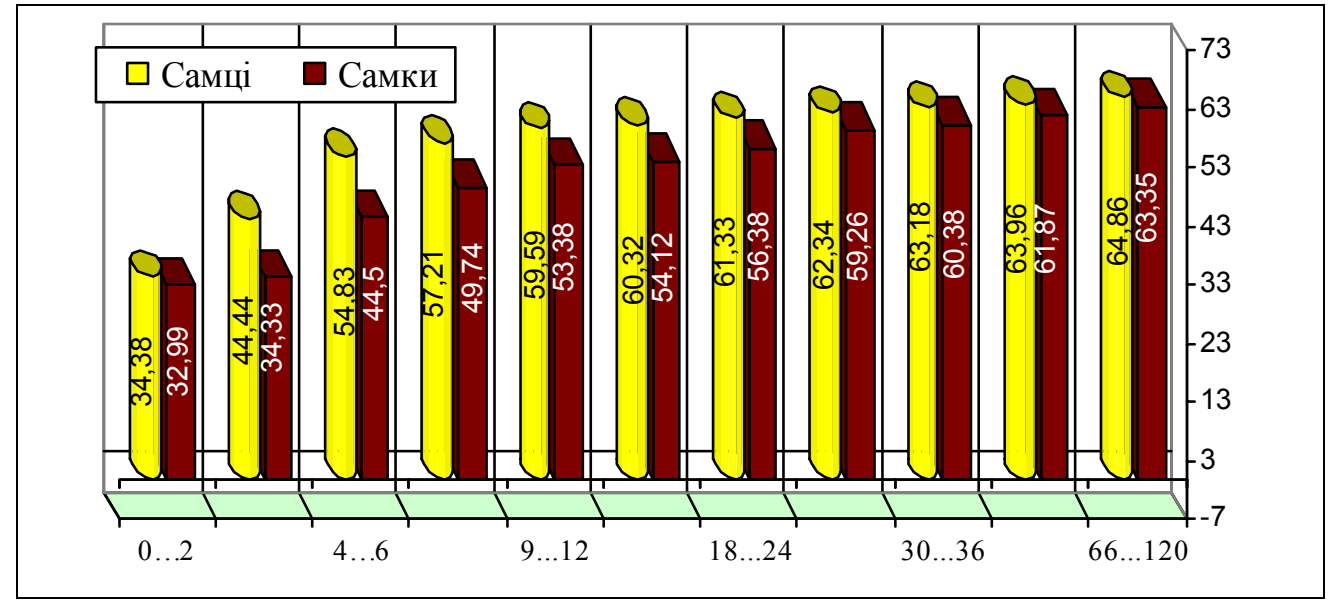

Рис. 8. Довжина піднебінної кістки ВРХ

Межове вікове значення ростральної ширини кісткового піднебіння становить для самців 15 місяців, а для самок - 35 місяців.

Довжина кісткового піднебіння самців і самок ВРX достовірно збільшується від народження до кінця терміну дослідження, зокрема у самців на $46,99 \%$, а у самок - на $47,92 \%$ (рис. 8 ). Так, найменшим це значення є в 1-й віковій групі (24 міс.) і становить у самців - 34,38 $\pm 0,53$ мм, що має тенденцію до збільшення на 4,21 \% проти аналогічного краніометричного показника самок $-32,99 \pm 0,70$ мм.

Довжина кісткового піднебіння самців від народження до 12-місячного віку стрімко збільшується на 42,30 \% (p $\leq 0,001)$, а в наступні періоди постнатального онтогенезу і до завершення дослідного періоду (120-а доба) - характеризується збільшенням зазначеного виміру $(\mathrm{p} \leq 0,05)$, однак із незначною інтенсивністю.

Довжина кісткового піднебіння самок від народження до 12-місячного віку стрімко збільшується на $38,20 \%(\mathrm{p} \leq 0,001)$, а в наступні періоди постнатального онтогенезу і до завершення до- слідного періоду (120-а доба) характеризується збільшенням зазначеного виміру $(\mathrm{p} \leq 0,05)$, але 3 незначною інтенсивністю.

Максимального значення аналізований краніометричний параметр досягає у самців і самок BPX 11-ї вікової групи (66-120 міс.): у самців $64,86 \pm 2,44$ мм, що характеризується тенденцією

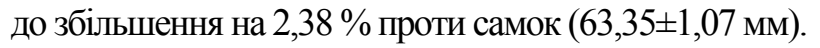

Межове вікове значення довжини кісткового піднебіння становить для самців 14 місяців, а для самок - 35 місяців.

\section{Висновки:}

1. Лінійні морфометричні параметри вентральної поверхні носо-мозкового відділу черепа як самок, так і самців ВРХ збільшуються від народження до 10-річного віку.

2. У динаміці морфометричні параметри вентральної поверхні носо-мозкового відділу черепа реєструється два періоди: домежовий період (від народження до межового критерію, відповідає відносно інтенсивному росту кісток черепа) i постмежовий період (від межового критерію віку до кінцевого терміну дослідження, в цей час 


\section{СТОРІНКА МОЛОДОГО ВЧЕНОГО}

уповільнюється збільшення розміров кісток черепа).

3. Межовий критерій віку за краніометричними параметрами ВРХ становить: за ростральної ширини кісткового піднебіння - для самців 15 міс., а для самок - 35 місяців; за довжиною черепа - для самців 10 міс., а для самок - 20 місяців; за довжиною беззубого краю - для самців 15 міс., а для самок - 10 місяців; за довжиною тіла потиличної кістки: для самців і самок - 20 місяців; за довжиною хоан - для самців 15 міс., а для самок - 30 місяців; за шириною хоан - для самців 15 міс., а для самок - 20 місяців; за аборальною шириною кісткового піднебіння - для самців 15 міс., а для самок - 25 місяців; за ростральною шириною кісткового піднебіння - для самців 15 міс., а для самок - 35 місяців; за довжиною кісткового піднебіння - для самців 14 міс., а для самок - 35 місяців.

\section{БІБЛІОГРАФІЯ}

1. Чернявский M. B. Анатомо-топографические основы технологии, ветеринарно-санитарной экспертизы и товароведческой оценки продуктов убоя животных : справочник / М. В. Чернявский. - М. : Колос, 2002. - 376 с.

2. Яценко I. В. Судово-ветеринарне значення структурних параметрів скелета ссавців для визначення видової належності біологічного матеріалу / І. В. Яценко, П. М. Гаврилін, О. М. Гетманець // Проблеми зооінженерії та ветеринарної медицини : зб. наук. праць Харківської державної зооветеринарної академії. - Х., 2014. - Вип. 28, Ч. 2. - С. 223-258.

3. Яизенко I. В. Анатомічні особливості черепа як критерії встановлення видової належності дрібних тварин у судовій біологічній експертизі / I. В. Яценко // Проблеми зооінженерії та ветеринарної медицини : зб. наук. праць Харківської державної зооветеринарної академії. - Х. : РВВ ХДЗВА, 2007. - Вип. 15 (40), Ч. 2. - Т. 1. С. 259-265.
4. Виявлені вікові закономірності метричних параметрів вентральної поверхні носо-мозкового відділу черепа ВРХ покладено в основу способу визначення віку та статі тварини за такими інформативними морфометричними параметрами: довжиною черепа, довжиною беззубого краю носомозкового відділу черепа, довжиною тіла потиличної кіски, довжиною і шириною хоан, аборальною шириною кісткового піднебіння, ростральною шириною кісткового піднебіння, довжиною піднебінної кістки ВРХ.

Перспективи подальших досліджень полягають у розробці способу визначення віку і статі BPX за встановленими особливостями динаміки краніометричних показників та створення комп'ютерної програми «Craniumvacce» для автоматизації краніологічних досліджень і оформлення результатів експертизи.

4. Рудик C. K. Спланхнокраній Bovidae u Cervidae / С. К. Рудик. - К. : Академія наук вищої освіти України, 2008. - 208 с.

5. Яценко I. B. Методичні підходи до остеоскопічного та остеометричного дослідження носомозкового відділу черепа великої рогатої худоби в аспекті судової ветеринарної експертизи / I. В. Яценко, Карем Р. С. Абузнайд // Проблеми зооінженерії та ветеринарної медицини : зб. наук. праць Харківської державної зооветеринарної академії. - Харків, 2014. - Вип. 28, Ч. 2. C. 200-207.

6. Regodon $S$. Etude radiologique des variation topographiques cranio-encephaliques chez les chiet dolicho-, meso- et brachycephales / S. Regodon, J. M. Vivo, A. I. Mayoral, A. Robina, Lignereux // Rev. Med. Vet. - 1990. - V.141. - P. 479-483.

7. Ragni B. Multivariate analysis of craniometric characters in European wild cat, domestic cat, and African wild cat (genus Felis) / B. Ragni, E. Randi // Z. Saugetk. - 1986. - Bd. 51. - P. 243-250. 